\title{
Male Domination and Psychological Manipulation: Toxic Masculinity in Paula Hawkins' The Girl on the Train
}

\author{
Manisha Sinha
}

Amity Institute of English Studies and Research (AIESR), Amity University, Noida, India

\section{ABSTRACT}

The term 'toxic masculinity' refers to the negative aspects of the traditional norms associated with manliness. Terry Kupers (2005) identifies misogyny, domination and aggressive competition and wilful violence as some of the traits of toxic masculinity. The antagonist in Paula Hawkins' The Girl on the Train is a man named Tom Watson, who demonstrates various traits associated with the concept of toxic masculinity. Another male character, Scott Hipwell, exhibits a volatile temperament and subjects his wife Megan to domestic abuse. This interdisciplinary research attempts to identify and examine instances of toxic masculinity and its deleterious effects on its intended victims in this novel. The theoretical framework of this paper comprises gender theories and concepts of psychological manipulation, such as passive-aggressive behaviour and gaslighting.

KEY WORDS: TOXIC MASCULINITY, DOMESTIC VIOLENCE, MARITAL ABUSE, GASLIGHTING, FEMINISM, PAULA HAWKINS.

\section{INTRODUCTION}

Masculinity refers to a complex set of attributes and traits associated with men and the male body by society at any given point of time (Berger, Wallis and Watson 1995; Mosse 1998). Toxic masculinity is a cultural concept that describes the negative aspects associated with manliness. Kupers (2005) defines toxic masculinity as the "constellation of socially regressive male traits that serve to foster domination, the devaluation of women, homophobia, and wanton violence" (714). Some of the 'toxic' traits associated with patriarchal notions of masculinity are that men should supress feelings of fear, weakness, sentimentality and so on, and that they should demonstrate aggressiveness, dominance, a violent streak, display of power etc. (Horrocks 1994). Male domination of women is one of the traits attributed to toxic masculinity. It can be achieved though force, inducement or manipulation. Manipulation is a morallyproblematic sophisticated phenomenon, an exercise of power, located in the grey area among coercion,

Biosc Biotech Res Comm P-ISSN: 0974-6455 E-ISSN: 2321-4007
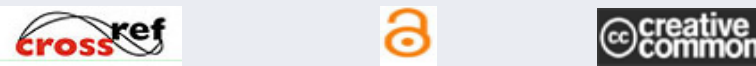

Identifiers and Pagination

Article Information

Year: 2021 Vol: 14 No (8) Special Issue

Received: $10^{\text {th }}$ Apr 2021

Pages: 109-114

Accepted after revision: $24^{\text {th }}$ June 2021

This is an open access article under Creative

Commons License Attribn 4.0 Intl (CC-BY).

DOI: $h t t p: / / d x$.doi.org/10.21786/bbrc/14.8.27 persuasion and deception. (Rodinow 1978; Goodin 1980; Handelman 2009, Todd 2013). Exploring a link between toxic masculinity and emotional manipulation, Rachel Grieve et al. (2019) report that "masculine gender roles powerfully predict emotional manipulation" (161). Research reports that men in extramarital relationships get an ego boost and may see their affair as validation of their "own sense of selves as masculine" (Walker 2020).

This paper examines traits of toxic masculinity and its deleterious effects on its intended victims in Paula Hawkins' The Girl on the Train. This critically-acclaimed novel, first published in 2015, is a psychological thriller. With a grim setting, plot focus on female experiences and relationships, and major action within homes, this crime fiction finds a place in the subgenre of domestic noir. The multinarrative story unfolds from the perspectives of three women. The protagonist of the novel, Rachel, is one of the narrators. She suffers from anterograde amnesia caused by alcoholic blackouts (Giovanelli 2018). Initially, she is shown as being obsessed with her ex-husband Tom Watson, who has moved on and married Anna. She becomes an alcoholic to cope with loss, pain and grief. However, as the layers of this psychological thriller peel off, it becomes clear that unknowingly, she has become a victim of Tom's manipulations and gaslighting. The term 'gaslighting' finds its origins in the play Gas Light (1938), in which a man psychologically manipulates his wife into making her doubt her perception of reality. 
Gaslighting is a type of psychological abuse aimed at gaining interpersonal control, manipulating the realities of victims (Sweet 2019). Gass and Nichols (1988) view gaslighting as a marital syndrome in the context of certain behaviours of adulterer men and their impacts on their spouses. All three female narrators-Rachel, Anna and Megan-are subjected to gaslighting by men in the selected text.

Discussion And Analysis: In the beginning of the novel, Rachel is shown as being in awe of her ex-husband. But on a subconscious level, she has an idea of what was lacking in her marriage. Enamoured of a couple-Megan and Scott Hipwell-whose house falls on the route of her daily train commute, she watches them from the window of the train and admires their chemistry. "He is kind and strong, everything a husband should be," she thinks of Scott (Hawkins 31). She gets the vibe, without knowing the couple personally, that they complement each other. "[T]hey are a partnership. I can see it... His strength, the protectiveness he radiates, it doesn't mean she's weak. She's strong in other ways," she feels (31).

Although she does not know even their names at this stage, she thinks a lot about them and places those qualities and values in their characters in her imagination, the lack of which she has suffered in her own romantic life. To her, they are an ideal couple, though it soon becomes obvious to her that she had been living in a self-constructed delusion about them, triggered by the initially similar and later contrasting memories of her own relationship with Tom. Therefore, when she realises that Megan is cheating on her partner, Rachel feels betrayed. She states, "A familiar ache fills my chest. I have felt this way before. On a larger scale, to a more intense degree, of course, but I remember the quality of the pain" (49).

Psychological Manipulation: The backstory of the RachelTom relationship is revealed in fragments, recounting incidents in no particular order, which reflects the jumbled thoughts and memories in the mind of the unreliable narrator. The author also uses the nonchronological backstory device to heighten the 'thriller' quotient of the plot. Rachel meets Tom after her father's demise. She sees him as a saviour who has helped her cope with grief. She is a "happy, solvent, successful" twenty-six-year-old woman when she marries Tom and co-buys a house with him at number twenty-three, Blenheim Road, where she lives for the next five years (Hawkins 77). Rachel's happiness hits a roadblock when she is unable to have a child.

She wants to have another round of in vitro fertilization (IVF) attempt when the first one fails, but Tom tells her that they do not have enough money for that purpose. But he goes with his friends to Las Vegas on a four-day trip to "watch the big fight and let off some steam" (253). Rachel has a fight with her husband on this issue, but she does not remember the details because of her elusive memory after heavy drinking. Tom uses this to his advantage, and psychologically manipulates her into hating herself for things she did not do. She says: I remember him telling me, in flat disappointed tones, what I'd done and said, and how I'd smashed our framed wedding photograph, how I'd screamed at him for being so selfish, how I'd called him a useless husband, a failure. I remember how much I hated myself that day. (254).

Tom tells her that they can continue living happily as a childless couple, but does not offer her the comfort and support she needs at that time. He displays passive-aggressive behaviour, a form of non-verbal aggression that manifests in destructive behaviour and is used as a tool of emotional abuse in relationships (Harnn 2011). In both verbal and non-verbal ways, Tom expresses frustration over her sadness instead of trying to understand her emotional pain and helplessness. He makes her think that while he can easily live without concerns about not having a child, she is the one obsessing over it. But on a subconscious level, she gets the feeling that Tom certainly wants to enter fatherhood. "He wanted to be a dad, he really did I'm sure he daydreamed about kicking a football around in the garden with his son, or carrying his daughter on his shoulders in the park" (112). People leading distressed or lonely life within their partnerships tend to have an elevated risk of both illness and depression (Cacioppo et al. 2002).

Isolated in her misery, Rachel, who has always been a drinker, becomes a drunkard as she turns to alcohol to counter loneliness and drown her sorrows. Her husband continues to make her life more miserable by physically and emotionally abusing her while he has a secret extramarital affair. One such instance is their argument, leading to Rachel being upset about the fact that he did not rush to her help when she accidently fell in his presence. Next day, she does not remember what happened afterwards. Tom lies to her that he attempted to "kiss and make up," but she tried to "take his head off" by attacking him with a golf club (297). In reality, she was the one threatened with a fatal assault with that weapon. Gaslighted by Tom, she blames herself for her misery and the downfall of their relationship. "After all he gave up for me, for the two of us to be together, I let him think that he wasn't enough" (77).

Tom makes her feel that she is ruining their relationship, even though she is the one who remembers their forthcoming anniversary and plans to surprise Tom with a special getaway. But when she accesses his computer surreptitiously to check his work schedule before booking the trip, she stumbles upon his email inbox and shockingly discovers about his extramarital affair with Anna Boyd. She is disgusted to find out that Tom has said the same flirtatious dialogue to woo Anna, that he had used for Rachel years ago. This leads to their divorce, but Tom continues to manipulate Rachel even afterwards. She does not have enough money to buy him out, so she wants to sell the house and get her share. Tom tells her that he will buy her out and "stay on until he got the right price for it" (56). He gives her the impression that although he is trying, he is unable to find a right 
buyer, and so, he continues living in that house even after his remarriage.

As Handelman (2009) states, fabricating "an illusion of free choice" for the intended victim is a characteristic of manipulatory behaviour (5). Tom enjoys the comfort of their home while Rachel, believing her ex-husband, becomes homeless and has to stay at a spare room in the house of her "half-friend" Cathy (Hawkins 23). Later, Tom cheats on Anna as well. He also emotionally manipulates her into believing that Rachel is obsessive about him and contacts him frequently even though he wants to maintain a respectful distance from her. As a result, Anna mistakes Megan's calls as those from Rachel. Thus, Tom makes Anna antagonistic towards Rachel while covering the tracks of his clandestine affair with Megan. In doing so, he also manages to command respect and affection from all these women. He makes each of them believe that he cares for her. Rachel, unable to see through deceptions, continues to trust him. With his deceitful gestures and attitude, he even makes her think that he has a soft corner for her. Anna also believes that Tom is doing his best to keep her and their daughter safe from his ex-wife. Because he has implied that Rachel is still in love with him and keeps pestering him on phone and keeps hovering near their residence, Anna considers her a stalker. Some of Rachel's actions only strengthen Anna's belief that the former is dangerous.

Gaslighting: Megan, on the other hand, has an extramarital affair with Tom when he is married to Anna. When Megan gets pregnant with his baby, she wants to inform Tom of the possibility that he might be the father. Megan sees Tom coming out of the underpass close by the railway station. He tells her to get into his car so that they could drive to a secluded place where no one might catch them together. As Megan is getting into the car, she feels that somebody is watching them from the dark underpass. She does not know that Tom violently attacked his ex-wife minutes ago. But when she notices blood on his hand and asks him about it, he evasively blames it on "[p]roblems with the ex" (384). He takes her to Corly Wood, thinking that she wants to have sex with him. But she makes it clear that this meeting is not another of their sexual escapades. She tells him that she is pregnant, to which he responds, "Have an abortion... if it's mine, get rid of it" (386).

Although she gives him the choice to be only as involved with the baby as he wishes to, Tom, in line with his habit of gaslighting, tells her she would be terrible as a mother, and that she must get the foetus aborted. His dismissal of Megan as 'motherhood material' enrages her and she refuses to have an abortion and go out of his life. Instead, she threatens him of repercussions. Tom is furious, knowing that this would not only wreck his familial life but might also expose his history of manipulative behaviour and cheating on his romantic partners. He kills the pregnant woman mercilessly and returns home, giving his wife no reason to be suspicious of him. Next day, he sends a voicemail to Rachel: I want to make sure you got home all right. You were in some state last night. Look. I'm sorry that I yelled last night, that things got a bit... overheated. I do feel sorry for you, Rachel, I really do, but this has just got to stop. (67).

He is sure that his alcoholic ex-wife must have had only blurry memories of last night. So, he subjects her to psychological abuse again. First, he shows fake concern towards the woman whom he hit badly and left alone in the underpass. Then, knowing that her wound and her overall condition would need some explanation, he blames all of that on her 'state.' Being aware that she might recall some hazy fragments of the incident either presently or later, he adopts a safe stance and vaguely hints that their last meeting was not cordial. Continuing to gaslight her, he displays faux sympathy for her, hinting that she is the one responsible for her present condition. Making it all about Rachel's obsession of him and her apparent stalking behaviour, he leaves a piece of advice for her at the end of the message, that she needs to put an end to her 'wrong' actions. Thus, the ruthless murderer makes his alcoholic ex-wife, who has memory problems, feel guilty for something she has not done. This is part of his plan to cover up his crime. Through this message, he has provided himself with an alibi. On the other hand, an emotional Rachel falls into his trap, feels sorry for herself and has more respect for him. She states: I play the message a second time, listening to the kindness in his voice, and the tears come. It's a long time before I stop crying... I don't know what I did to Anna, how I frightened her... I don't honestly care that much, but I do care about making Tom unhappy. After everything he has been through, he deserves to be happy. (67)

She writes him an apology via mobile text message even though she does not remember doing anything wrong. She feels sorry only because he makes her feel guilty. For several days, Rachel finds herself implicated in the murder case as a possible culprit. Having been gaslit for years by Tom, she doubts herself to the extent that she worries that she might have harmed Megan under the influence of alcohol. She does not remember doing anything criminal, but her experience with Tom has taught her to accept herself as an unreliable and violent woman who commits blunders and forgets about her harmful actions. There are instances in the past where Tom accuses her of hitting him, and even though she denies hitting him or anyone else in her entire life, he shows bruises on his body and convinces her to be distrustful of herself. Even though she fails to "reconcile the violence that he talked about with the fear" she remembers experiencing, she learns not to argue with Tom and instead, accepts the information he gives as the truth (336).

In fact, he once gave her a book written by a doctor about blacking out, after making Rachel feel that she had exhausted him with her damaging actions. He leaves no stone upturned in making certain that Rachel self-doubts and self-loathes. During their married life, he even threatens to record her blackout moments but never does so, because his versions are lies. But at that time, Rachel feels thankful that her husband does not 
record and play the recordings for her. "Small mercies," she thinks (336). To suit his motives, Tom has trained her to feel sorry and apologise unconditionally for things he tells her she did, though she actually did not do any negative action. Hence, regarding Megan's disappearance too, Rachel feels responsible for doing something terrible which she is unable to recall because of her memory blackout problem. She wonders, "What could I have done? Gone to Blenheim Road, attacked Megan Hipwell, disposed of her body somewhere and then forgotten all about it? (97).

Trying to join the dots together to figure out what happened during the night of her blackout and Megan's disappearance, when Rachel reaches out to Tom desperately for help, he shows an utter disregard towards her genuine concern. He gaslights her further, saying, "I'm surprised you remember anything at all, Rachel. You were blind drunk. Filthy, stinking drunk... You'd fallen over in the street, you were crying, you were a total mess" (Hawkins 334). Not only the words that he utters, describing her state that night, but the way he speaks- "his voice loud, harsh," "sounds really annoyed," "another heavy sigh," "wearily," "sounds irritated"-depicts his negative attitude towards his exwife (Hawkins 333-334). On the day of Megan's murder, Tom finds Rachel in the underpass and physically assaults her, "one slap across the mouth and then his fist raised, keys in his hand," smashing down on her skull with the jagged metal (337).

When Rachel finally recalls that Tom is the one who attacked her on the fateful night of Megan's murder, and understands that he has been manipulating and gaslighting her for years, she goes to his house and confronts him. Tom tries to justify his non-justifiable deeds and pins the entire blame on Rachel. He insists that he was a good husband to her and tolerated her a lot until they parted ways. When she points out that he exploited her trust and vulnerability, made her feel worthless and watched her suffer, he speaks with contempt: Do you have any idea how boring you became, Rachel? How ugly? Too sad to get out of bed in the morning, too tired to take a shower or wash your fucking hair? It's no wonder I lost patience, is it? It's no wonder I had to look for ways to amuse myself. You've no one to blame but yourself. (380).

One of the importance clauses in the Catholic wedding vows is to hold one's spouse in sickness and in health. Another is to be there for each other in both good and bad times. Tom despises Rachel for being in emotional pain. He is emotionally unavailable for her when she needs it the most. An option for a person who is not in love with his spouse anymore is divorce, which allows both of them to go their separate ways. But Tom continues living with her and has a secret sexual relationship with Anna. He repeats the same behaviour of cheating on his wife after divorcing Rachel and marrying Anna. This shows that he is a serial cheater, liar and manipulator. As Christin L. Munsch (2012) states, infidelity is a dynamic social process which is "subject to influence by the context in which it is embedded" (46). An analysis of Tom's character shows that he has an ego-syntonic attitude towards his life choices, including his decision to commit adultery.

Therefore, he is not repentant at all when his secret affairs are exposed. Each time, Tom places the fault on the victim-the woman being cheated on, and presents himself as a choiceless victim of circumstances. He betrays Anna's trust when he has a fling with Megan at a time when Anna is dealing with postpartum life, "still fat, exhausted, raw, off sex" and embracing motherhood, while being deeply in love with her husband (342). He tries to justify his sexual fling with Megan to Anna by blaming her for being unavailable for sex. He tells her, "You were so tired all the time. You just weren't interested. Everything was about the baby. Isn't that right? It was all about you, wasn't it? All about you! (379)."

Thus, he tries to prove that his cheating behaviour was reasonable and Anna was responsible for his infidelity. There is no place for spelling out concerns and talking out differences in his thought process. He gaslights his second wife into thinking that she behaved selfishly and ignored the interests of her husband, who then had no choice but to seek sex outside marriage. He, however, contradicts his own stance that Anna was concerned only about herself, by saying that her world revolved around their new-born daughter at that time. Now that he has been caught red-handed, he is left with no option but to accept that he had an affair with Megan. Yet, he takes even this situation as an opportunity to boast about being honest to his wife. "You think I'm being cruel, but I'm not. I'm telling the truth. That's what you want, isn't it, Anna? You asked me not to lie," he tells Anna (379). Showing both shrewdness and passive-aggressive behaviour, Tom twists the narrative to suit his best interests. He tries to generate sympathy from his wife, whom he cannot afford to alienate at the moment.

When Rachel tries to make a call to the police, Tom does not think twice before attacking her violently. He attempts to kill her, but not without justifying that as well. He tells Rachel, "What am I supposed to do with you? What choice are you giving me?... You admit to admit it. You've brought this upon yourself" (399). Here, his toxic behaviour reaches its peak as he blames Rachel for getting killed by him. On the spur of the moment, Anna realises that she cannot trust her husband anymore. If he can kill his paramour and his ex-wife, he can kill his present wife too. Anna sees through Tom's character and refuses to become a victim of his manipulative behaviour again.

When Rachel stabs a corkscrew into the throat of her attacker, Anna unexpectedly pushes it deeper to make sure that he dies. Anna also saves Rachel from possible arrest, telling the police that the latter killed Tom in self-defence. After Tom's death, a lot of secrets come out in the open through news media. He had lied to both Rachel and Anna to keep them away from his 
family, who might reveal his past which he had glossed over to present a clean image of himself. In reality, he had squandered his parents' savings and wanted them to remortgage their house to lend him more money. It was then that they cut ties with him. Rachel also comes to know through newspapers that Tom had lied about having been in the army. She realises: He lied all the time, about everything. Even when he didn't need to, even when there was no point... Tom's whole life was constructed on lies-falsehoods and half-truths told to make him look better, stronger, more interesting than he was. (405).

Toxic Masculinity: Attributes such as strength are perceived as desired qualities in men, tied to the social construct of masculinity. Another character in the novel who exhibits traits of toxic masculinity is Scott Hipwell, Megan's husband and a self-employed IT consultant. He shows aggressive behaviour and physically assaults both Megan and Rachel. He even keeps the latter in unlawful detention for some time, after his wife goes missing and he has a fling with Rachel.

Prior to this incident, Scott is shown as a loving husband with possessive attitude towards Megan. He also trespasses her personal boundaries several times in the novel. He is a domineering husband who disregards his wife's wishes and preferences. Megan, who worked as waitress and a gallery manager in the past, is currently unemployed. Scott is unable to understand that his wife desperately wants to get back to work to keep herself occupied, and the last thing she needs is rest. He keeps telling her that she should rest, rather than worry about working. His advice irks her and makes her feel like an invalid. Nevertheless, he is excited to hear that she is going to be a babysitter for Anna's baby. He wants to have children and mistakenly thinks that being around babies will change her mind about having her own baby. He is so obsessed at the prospect of changing Megan's mind regarding starting a family that he fails to see that his wife is not happy doing this 'nanny' job.

Scott is an intrusive man who checks on his wife's personal stuff such as her diary and email. He snoops on her computer in her absence and covers his tracks by deleting browser history, so that she would not suspect him. But Megan knows that she cannot trust him, therefore she does not keep a personal diary as recommended by her therapist. She also has a troubled past, but she does not trust Scott enough to confide in to him, though they have been married for three years. He has no idea about her relationship in her teenage years with a man named Craig McKenzie, who had dumped her after she had accidently killed their baby. At present, when Scott secretively checks Megan's browser history and discovers search logs for a 'Craig', he fights with her and injures her. The description of their fight as "one off the bruising ones" shows that Scott has hurt her before too, more than once (87). Clearly, he is over-possessive and has anger management issues. Megan's therapist Kamal suggests that she is afraid of Scott, but she instantly declines being fearful of him. Kamal explains to her that she might have internalised her husband's toxic behaviour as a norm, and tells her:

The behaviour you are describing - reading your emails, going through your internet browser history - you describe all this as though it is commonplace, as though it is normal... It isn't normal to invade someone's privacy to that degree. It is what is often seen as a form of emotional abuse. (88) Megan, however, is so used to the invasion of her privacy that she denies that her husband is not abusing her since she does not mind him snooping around. Notwithstanding, she admits that Scott has a jealous and possessive nature. But she thinks that "some battles aren't worth fighting for," therefore she does not pay heed to the negative aspects of his behaviour (88).

Later in the novel, when Megan finds out she is pregnant, she decides to tell Scott the truth. She is mentally prepared to accept his possible decision to leave her after knowing about her infidelity, but she is not prepared to experience the violent side of him. Upon hearing only a part of her confessions, Scott loses his cool and becomes violent. He chokes her throat and almost kills her in a fit of anger. Megan describes the assault thus: I cough and spit, tears running down my face... I open my mouth but the words won't come, just more coughing. The pain is unbelievable... I bring my hand up to my face: it looks startingly white against my reddened skin, my purple lips, my bloodshot eyes. (366) She finally realises that deep inside, she expected Scott to batter her like this, as she had experienced his aggressive manners earlier as well. But while she concedes that she had a subconscious idea about her husband's pattern of toxic behaviour, she takes the blame for leading him in the direction of violence. It is evident that she has internalised the notions attached to toxic masculinity so deeply that she justifies Scott's pugnacious actions. In a patriarchal society, a man is expected to punish his wife by verbally or physically assaulting her if she is unfaithful to him, because her adultery is seen as a direct attack on his manliness.

\section{CONCLUSION}

There are several instances in The Girl on the Train that demonstrate the psychological manipulation and male domination of women. Rachel, Anna and Megan suffer at the hands of men at various points in the novel. None of them are portrayed as angelic women. The author does not put them on a pedestal so as to contrast them with the oppressive men in their lives. They are represented as real, relatable ladies who have been wronged by men. These women are flesh and blood, having negative characteristics as well. Rachel has a serious drinking problem; Anna looks down upon her husband's ex-wife; and Megan indulges in adultery. However, this does not justify the emotional torture and physical assaults that they are subjected to. An important aspect of toxic masculinity is that men should keep women in control. If a woman has any fault, she is often blamed for those things also which she has not done, while the misdeeds of oppressive husbands are often justified by society. 
Drinking by women has often been used as an excuse by patriarchy to show them as loose, immoral who deserve to be mistreated. Tom takes his thinking a notch higher as he manipulates her into believing that she is a worthless, savage woman who does violent things that she cannot even remember later. Tom is unfaithful to his second wife, too. In both cases, he self-identifies as a good husband and holds his spouse responsible for his 'straying'. He also 'orders' Megan to abort the baby, and kills her when he smells rebellion. During her lifetime, she is wronged by three men in her life, but she tries to bring her personal and professional life back on track. Megan is no 'shrew' who needs to be tamed. Scott could choose to go with her to a marriage counsellor or file for divorce, but instead he uses physical force on her. The ideology of toxic masculinity dictates that men are right to punish 'wanton' women, especially if these females are their family members.

Men who cannot keep the women of their family under their control are labelled as unmanly or unmasculine. Scott not only invades the personal space of Megan by checking her messages and emails, but also tries to keep a tab on her movements. The analysis of this text shows that gaslighting is not only a psychological phenomenon but a sociological one as well, thereby corroborating Paige L. Sweet's (2019) theory that gaslighting is "rooted in social inequalities, including gender, and executed in power-laden intimate relationships" (851). The novel depicts how men who have internalised toxic masculinity believe in their distorted version of truth, which are blatant lies in reality.

\section{REFERENCES}

Cacioppo, John T., et al.( 2002) "Loneliness and health: Potential mechanisms." Psychosomatic Medicine 64.3, pp. 407-417.

Gass, G.Z., Nichols, W.C. (1988) Gaslighting: A marital syndrome. Contemp Fam Ther 10, pp. 3-16. https://doi. org/10.1007/BF00922429

Giovanelli, Marcello. (2018) 'Something Happened,
Something Bad': Blackouts, Uncertainties and Event Construal in The Girl on the Train." Language and Literature, vol. 27, no. 1, Feb., pp. 38-51, doi:10.1177/0963947017752807.

Goodin, Robert E.( 1980) Manipulatory politics..

Grieve, Rachel, Evita March, and George Van Doorn. (2019) "Masculinity might be more toxic than we think: The influence of gender roles on trait emotional manipulation.” Personality and Individual Differences. 138, pp. 157-162.

Handelman, Sapir. (2009) Thought manipulation: the use and abuse of psychological trickery. ABC-CLIO,.

Harrn, Andrea. (2011) "What is Passive Aggressive Behavior?." Counselling Directory. Memiah Limited. May 13.

Hawkins, Paula. (2015) The Girl on the Train. Random House.

Horrocks, Roger. (1994) "Masculinity in crisis." Self \&t Society 22.4, pp. 25-29.

Kupers, T.A. (2005) Toxic masculinity as a barrier to mental health treatment in prison. J. Clin. Psychol., 61, pp.713-724. https://doi.org/10.1002/jclp.20105

Mosse, George L. (1998) The image of man: The creation of modern masculinity. Oxford University Press,.

Munsch, C.L.( 2012) The Science of Two-Timing: The State of Infidelity Research. Sociology Compass, 6, , pp. 4659. https://doi.org/10.1111/j.1751-9020.2011.00434.x Rudinow, Joel. (1978) "Manipulation.” Ethics 88.4, pp. 338-347.

Sweet, Paige L.( 2019) "The Sociology of Gaslighting." American Sociological Review, vol. 84, no. 5, Oct., pp. 851-875, doi:10.1177/0003122419874843.

Todd, Patrick. (2013 )“Manipulation.” International Encyclopedia of Ethics.

Walker, Alicia M. (2020) Chasing Masculinity: Men, Validation, and Infidelity. Springer Nature.

Watson, Maurice Berger Brian Wallis Simon. (1995) Constructing Masculinity. No. 11. Psychology Press. 